\title{
The consequences of neglect in children: neurocognitive comparisons among conduct disordered and non-conduct disordered youth residing in foster-care with that of children from intact families
}

\author{
David M. Compton \\ Dept. of Psychology, Palm Beach Atlantic University, West Palm Beach, FL, USA \\ Email address: \\ david_compton@pba.edu
}

To cite this article:

David M. Compton. The Consequences of Neglect in Children: Neurocognitive Comparisons Among Conduct Disordered and Non-Conduct Disordered Youth Residing in Foster-Care with That of Children from Intact Families. Psychology and Behavioural Sciences. Vol. 2, No. 3, 2013, pp. 96-105. doi: 10.11648/j.pbs.20130203.13

\begin{abstract}
Children $(n=85)$ between the ages of 6 and 16 were administered two tests of source monitoring proficiency, one an external source test and the second an internal source test. In addition, the children were assessed using the Children's Category Test (CCT), the Wechsler Intelligence Scale for Children-Third Edition (WISC-III), and the Wisconsin Card Sorting Test (WCST). The primary interest was to compare the source monitoring and cognitive processes of children in foster care with a diagnosed conduct disorder and children in foster care without a psychiatric diagnosis. In addition, a group consisting of children living with their parents was included for comparative purposes. For the primary analyses, the dependent variables consisted of raw ISM and ESM scores, full-scale IQ, measures of working memory and processing speed, and the total and perseverative error measures of the WCST. First, because age differences were expected, a MANOVA was used with the age of the subject grouped into three categories of 6 to 8-, 9 to 12-, and 13 to 16-year olds. Following the verification of age differences on the dependent measures, a MANCOVA was used to examine the influence of abuse/neglect by comparing individuals in foster care, with and without a psychiatric diagnosis. Therefore, the study comprised three groups: (1) a group of children living at home with the parents and serving as a comparison group, (2) a control group consisting of children living in foster care but with no psychiatric diagnosis, and (3) a group of children living in foster care with a diagnosed conduct disorder. Age, as a continuous variable, served as the covariate. ISM scores revealed that both of the control groups differed from the foster care / conduct disorder group, with scores in the foster care control group comparable to that of the intact family comparison group. The intact family comparison group had significantly higher FS-IQ scores than either foster care group. In addition, FS-IQ scores in the foster care control group were intermediate between that of the intact family comparison and conduct disorder groups. Children in the intact family comparison group made significantly fewer total errors and perseverative errors than either foster care group. However, the number of perseverative errors for the two foster care groups was comparable.
\end{abstract}

Keywords: Conduct Disorder, Memory, Executive Function, Foster-Care

\section{Introduction}

A large body of evidence suggests a link between deficits in neurocognitive processes and aggressive behaviors $[1,2]$. Research involving human and nonhuman animal subjects has been suggestive of a relationship between alterations in prefrontal cortical function and aggression [2-4]. Further the relationship appears to extend to antisocial behavior in humans [5], with centers of activity in both dorsal and ven- tral prefrontal cortex implicated [2]. For example, prefrontal cortex lesions confined to the ventromedial cortices are associated with impairments in affective decision-making and an increase in aggressive behavior [6,7].

On the basis of the available evidence of an "acquired sociopathy" [8] resulting from ventromedial cortical lesions, Blair [9] proposed a central regulatory role of the orbitofrontal cortex in reactive forms of aggressive behavior. The available research suggests that this region of the ventral prefrontal cortex is involved in such processes as the as- 
sessment of reinforcement contingencies [10-12] and the appraisal of affective information $[2,10]$ as well as the inhibition of impulsive behavior [2,10-12]. Medial frontal cortex areas such as the anterior cingulate cortex are central for self-monitoring, attention, and actions in behavioral circumstances that require the resolution of interpersonal conflict $[13,14]$.

Mistreatment of children in the form of physical abuse, emotional abuse, or neglect is a common societal problem estimated to affect more than $12 \%$ of all children [15]. A consensus has developed that settled the question concerning the effects of psychological and/or physical trauma on normal child development with the evidence squarely in the corner of demonstrating that the effects on child development are substantial [16]. Further, the detrimental effects extend to the cognitive and affective developmental domains [17-20]. Neurologically, childhood exposure to abuse has produced a variety of deficits including problems in executive functioning that include the ability to synthesize and categorize information [16], delays in language acquisition leading to learning disabilities, and problems of self-regulation and impulse control [21-24].

According to the criteria outlined in the DSM-IV-TR, conduct disorders in youth include a cluster of behaviors that are in violation with accepted societal norms or patterns of behavior that involve persistent transgressions against the basic rights of others [25]. While a number of causal factors have been proposed through the years including dysfunctions of the dominant hemisphere [26] or a maturational lag in frontal lobe development or dysfunction [27], the evidence remains inconclusive. With the growth in our understanding of the interplay between genetics and the environment, there is evidence of identifiable endogenous and exogenous risks [28]. Unfortunately after years of research, no single factor has been identified [29] resulting in a renewed emphasis on delineating subgroups of individuals with conduct disorders [30]. Some, such as a child-onset subgroup defined by low levels of fear and the absence of empathy (referred to as callous-unemotional) appear to have higher levels of heritability than other defined subgroups [30]. This subgroup appears to present with higher levels of behavioral and cognitive disturbances [31, 32]. In fact, children within this subgroup display disturbances in a manner similar to that observed in adult psychopathology [33].

Although current memory research indicates as many as five or more memory systems [34], traditionally memory has been distinguished between declarative and nondeclarative memory systems [35-37], with various memory systems defined within these [38]. Tests of declarative memory performance include activities that probe for conscious or explicit recollection [36] such as recall for your first day in college. In contemporary research [see 37], declarative memory has typically been subdivided into the episodic memory domain which includes memory about the occurrence of event (i.e., the personal narrative of an individual) and a semantic memory domain which involves facts and knowledge about the world, independent of a specific time and place (e.g., the knowledge that $\mathrm{E}=\mathrm{mc}^{2}$ ). Episodic memory then is related to the context of experience, including such things as where the experience occurred, when it happened, and what individuals (if any) were present [39]. Recall for such contextual information associated with a given memory is known as source monitoring [40].

The cognitive process normally referred to as source monitoring reflects the ability of the individual to attribute the origin of memories [40], including the context of individual memories such as those involving personal knowledge and beliefs [41]. Research into the nature of and changes in accuracy in source monitoring normally differentiate among three types of source monitoring, reality monitoring, eternal monitoring (ESM), and internal monitoring (ISM) [40-45]. Internal source monitoring involves the ability to distinguish between memories for internally generated events (e.g., "Last week, did I actually call her a 'drama queen' or did I only think it?"). The ability to accurately distinguish between memories from two external sources is considered external source monitoring (e.g., "Did I hear about Gabby Douglas' gold medal from NBC or from my wife?"). Finally, reality monitoring involves the ability to accurately remember whether a given memory came from within the individual (e.g., "Did I daydream about this?") or from an external source (e.g., "Did I hear about this in my biochemistry class?"). While errors in source monitoring are quite common they can have an impact on relationships and undermine the efficacy of eyewitness testimonies [46].

The current body of research supports the idea that episodic memory does not develop until the child is approximately three to four years old [34]. Three-year old children demonstrate considerable problems in recalling the source of acquired information [47-49]. Further, past research has indicated that, when compared to somewhat older children, children under the age of six are impaired in recalling whether they imagined or actually performed a behavior $[50,51]$.

The research was conducted in order to explore further the putative detrimental effects of severe stress resulting from abuse in the lives of children on general cognitive and memory functioning. The measures employed here included the assessment of overall intelligence, working memory, processing speed, frontal lobe function, and the ability to identify the source of information. Source monitoring performance was deemed important to include as deficits in source monitoring could directly impact appropriate and inappropriate behavior as well as interpersonal relationships. It was predicted that those children currently residing in foster care would show evidence of frontal lobe impairment as measured by such tools as the Wisconsin Card Sorting Test and source monitoring measures. Finally, problems in memory and intellectual performance were also predicted. 
Table 1. Relevant demographic information about the participants

\begin{tabular}{|c|c|c|c|c|c|c|c|c|c|}
\hline & \multicolumn{3}{|c|}{6 to 8-Year Olds } & \multicolumn{3}{|c|}{9 to 12 -Year Olds } & \multicolumn{3}{|c|}{13 to 16 -Year Olds } \\
\hline & $\mathrm{CD}^{\mathrm{a}}$ & Non-CD ${ }^{b}$ & Comp. $^{\mathrm{c}}$ & $\mathrm{CD}$ & Non-CD & Comp. & $\mathrm{CD}$ & Non-CD & Comp. \\
\hline N Children & $\mathrm{n}=5$ & $\mathrm{n}=10$ & $\mathrm{n}=10$ & $\mathrm{n}=10$ & $\mathrm{n}=10$ & $\mathrm{n}=10$ & $\mathrm{n}=11$ & $\mathrm{n}=9$ & $\mathrm{n}=10$ \\
\hline Age & $7.0(1.00)^{\mathrm{d}}$ & $6.9(0.88)$ & $7.30(0.82)$ & $10.7(1.16)$ & $10.3(1.06)$ & $10.3(1.16)$ & $14.6(1.17)$ & $14.6(1.13)$ & $14.91(0.83)$ \\
\hline $\operatorname{Sex}^{\mathrm{e}}$ & $100 \% / 0 \%$ & $30 \% / 70 \%$ & $40 \% / 60 \%$ & $90 \% / 10 \%$ & $50 \% / 50 \%$ & $40 \% / 60 \%$ & $40 \% / 60 \%$ & $56 \% / 44 \%$ & $73 \% / 27 \%$ \\
\hline $\operatorname{Race}^{\mathrm{f}}$ & $20 \% / 80 \%$ & $40 \% / 60 \%$ & $70 \% / 30 \%$ & $40 \% / 60 \%$ & $30 \% / 70 \%$ & $80 \% / 20 \%$ & $30 \% / 70 \%$ & $44 \% / 56 \%$ & $60 \% / 40 \%$ \\
\hline
\end{tabular}

Note. ${ }^{\mathrm{a}} \mathrm{CD}=$ Foster-Care,; Conduct Disorder Youth Group; ${ }^{\mathrm{b}}$ Non-CD $=$ Foster Care, No Conduct Disorder Group; ${ }^{\mathrm{c} C o m p .}=$ No Foster Care Comparison Group; ${ }^{\mathrm{d}} \mathrm{M}(\mathrm{SD}) ;{ }^{\mathrm{e}} \mathrm{Sex}=\%$ Male $/ \%$ Female; fRace $=\%$ Caucasian $/ \%$ African-American or Bi-racial.

\section{Method}

\subsection{Participants}

The present study included a convenience sample consisting of 85 children ( 38 girls \& 47 boys) ranging in age between 6 and 16 at the time of testing. The sample included 55 participants, drawn from foster-care settings due to parental or guardian confirmations of child neglect, physical and/or emotional abuse, or both. The thirty remaining children, 15 males and 15 females, resided with their parents and served as a comparison group. The families of these 30 children had no previous involvement of the legal system or state children and family services. In addition, the names of the comparison group participants were compared against active cases with local community services, which provided an active log of pre-teen and teenage children who receive mental health services for conduct and other mental health issues. For some analytic purposes, the three groups of children were further divided into three age groups -6 to 8 years $(M=7.08, S D=.862)$, 9 to 12 years $(M=10.4, S D=1.10)$, and 13 to 16 years $(M$ $=14.7, S D=1.02)$. Additional demographic information is provided in Table 1.

The children in the foster-care settings and those in the comparison group all attended public schools in a mixed urban and rural area located within a geographical area of approximately 1000 square miles in the southern part of the United States. Given the demographic composition of the area, the children can be considered as having come from similar cultural socioeconomic backgrounds.

\subsection{Materials and Procedure}

All children were tested on an external source monitoring and an internal source monitoring task. In addition, the children were tested using a standard battery consisting of the Wisconsin Card Sorting Test [52], Wechsler Adult Intelligence Scale for Children (3rd edition; WISC-III) [53], and the Children's Category Test-Level I (CCT-I; 6-8 year olds) or Level II (CCT-II, 9-16 year olds) as appropriate [54]. Working memory (WM) and processing speed (PS) measures for the WISC-III were calculated in a manner consistent with the literature $[55,56]$. The order of the source-monitoring and the standardized tests was counterbalanced as was the order of the internal and external source-monitoring tasks.

All behavioral testing occurred in a quiet room located in a testing laboratory. Testing began only after the participant indicated that they were comfortable and ready to begin. The ISM task followed Foley and Johnson's [50] Do-Pretend condition. Briefly, the child was verbally invited to play a detective game with the following instructions.

Good detectives are very careful not to give any clues about what they are thinking. So, sometimes I will ask you to do something and other times I will ask you to pretend or imagine yourself going through the motions involved in doing something else. When you imagine yourself doing something, be careful not to give me any clues or hints about what you are pretending to do. If you sit quietly in the chair, and rest your arms in your lap, it will help you not to give me any clues. [50, p. 1148].

A total of four actions, two from the "Do" condition and two from the "Think/Pretend" condition, were randomly selected from each of the six categories. An inter-action interval of five seconds was used throughout the task. Thus, collectively the task required that the child perform a total of 12 actions and pretended to perform an additional 12 . Immediately following this phase, the child was presented with a 60 second distractor task (alphabet song for 6-8 year olds or counting back by twos from 50 for the 9-16 year olds). Following the distractor task, the investigator read the list of actions having first instructed the child to recall which actions were performed and which were imagined. In addition, the child was told that some of the actions in the list were new and was instructed to identify any novel actions from the list.

The verbal directions associated with the external source monitoring task included instruction to listen to words where the correct pronunciation varied in difficulty. Participants were instructed to listen closely to the recorded words of a male or female speaker as they were played and to nod their head in the affirmative if the child said the word correctly or nod their head in the negative if the speaker did not pronounce the word correctly. 
At a rate of 3 seconds from a pool of 36 words, each child then listened to a recorded list of 24 words, 12 spoken

Table 2. Pearson Product-Moment Correlation Coefficients

\begin{tabular}{|c|c|c|c|c|c|c|c|c|}
\hline & Age & $\begin{array}{l}\text { WCST } \\
\text { Errors }\end{array}$ & $\begin{array}{c}\text { WCST } \\
\text { Persevera- } \\
\text { tive } \\
\text { Errors } \\
\end{array}$ & $\begin{array}{l}\text { Working } \\
\text { Memory }\end{array}$ & $\begin{array}{l}\text { Processing } \\
\text { Speed }\end{array}$ & ISM & ESM & $\begin{array}{c}\text { Full-Scale } \\
\text { IQ }\end{array}$ \\
\hline Age & --- & $-.407 * *$ & $-.369 * *$ & .100 & -.103 & $-.365^{* *}$ & $-.443 * *$ & -.104 \\
\hline WCST Errors & & --- & $.854 * *$ & $-.431 * *$ & $-.273 *$ & $.463 * *$ & $.468 * *$ & $-.451 * *$ \\
\hline $\begin{array}{l}\text { WCST Persevera- } \\
\text { tive Errors }\end{array}$ & & & --- & $-.401 * *$ & $-.301 * *$ & $.354 * *$ & $.371 * *$ & $-.461 * *$ \\
\hline Working Memory & & & & --- & $-.535 * *$ & $-.498 * *$ & $-.363 * *$ & $.642 * *$ \\
\hline Processing Speed & & & & & --- & $-.339 * *$ & $-.240^{*}$ & $.715^{* *}$ \\
\hline ISM & & & & & & --- & $-.430 * *$ & $-.444 * *$ \\
\hline ESM & & & & & & & --- & $-.237^{*}$ \\
\hline Full-Scale IQ & & & & & & & & --- \\
\hline
\end{tabular}

Notes. ${ }^{*} \mathrm{p}<.05 ;{ }^{* *} \mathrm{p}<.01$, two-tailed test. ISM $=$ Internal Source Monitoring. $\mathrm{ESM}=$ External Source Monitoring.

by an adolescent female and the remainder spoken by an adolescent male. Word and speaker order was determined randomly and the distractor task described earlier was used. Following the distractor task, the test administrator repeated a list of words and queried the child to identify each word as one that was heard earlier as spoken by the boy, the girl or a novel word.

\subsubsection{Data Analytic Strategy}

The primary interest was to compare the source monitoring and cognitive processes of children in foster care with a diagnosed conduct disorder and children in foster care without a psychiatric diagnosis. In addition, a group consisting of children living with their parents was included for comparative purposes. For the primary analyses, the dependent variables consisted of raw ISM and ESM scores, full-scale IQ, measures of working memory and processing speed as described earlier, and the total and perseverative error measures of the WCST. First, because age differences were expected, a MANOVA was used with the age of the subject grouped into three categories of 6 to 8-, 9 to 12-, and 13 to 16-year olds. Following the verification of age differences on the dependent measures, a MANCOVA with the living arrangement and psychiatric diagnosis comprising three groups: (1) a group living at home with the parents as a comparison (control) group, (2) a second control group consisting of children living in foster care but with no psychiatric diagnosis, and (3) a group of children living in foster care with a diagnosed conduct disorder. Age, as a continuous variable, served as the covariate.

\section{Results}

\subsection{Bivariate Correlations}

The bivariate correlations are presented in Table 2. Age was correlated ( $p<.01$, two-tailed test) with ISM, $r(83)=$ -.363 , ESM, $r(83)=-.443$, WCST total errors, $r(83)=-.407$, and WCST perseverative errors, $r(83)=-.368$, but not with the WM and PS measures or FS-IQ. In addition, the various dependent measures were intercorrelated with $r$ s ranging from -.237 to .854 .

\subsection{Age Effects}

As noted earlier, the next step in the analytic plan was to explore the effect of the age of the respondent on the performance of each of the dependent variables.
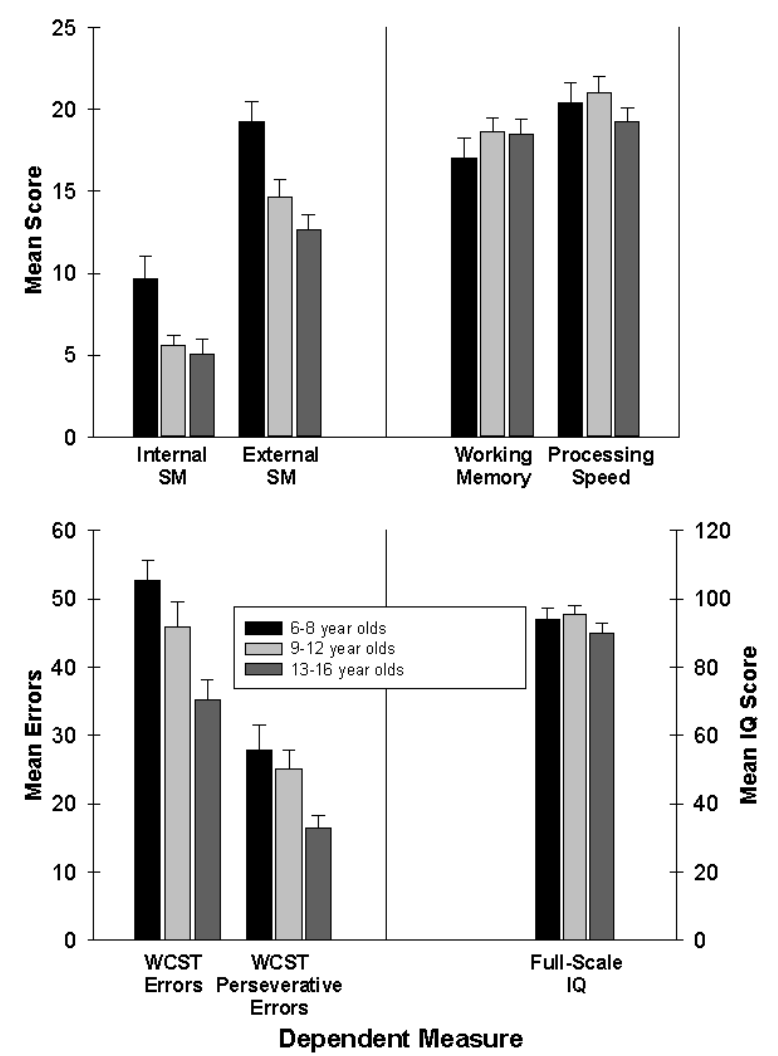

Fig 1. Age comparisons for each of the dependent variables

The MANOVA with Age as the independent variable was statistically significant, Wilks $\lambda=.565, F(14,152)=3.59$, $p<.001$. As can be seen in Fig. 1, Post hoc ANOVAs indicated significant group differences on the following 
dependent measures. ISM scores differed as a function of age, $F(2,82)=6.00, \mathrm{p}<.01, \eta^{2}=.128$, with 6 to 8 -year olds making significantly more errors than the 9 to 12 - and 13 to 16-year olds where the group performances were comparable. Similarly, group differences in ESM scores
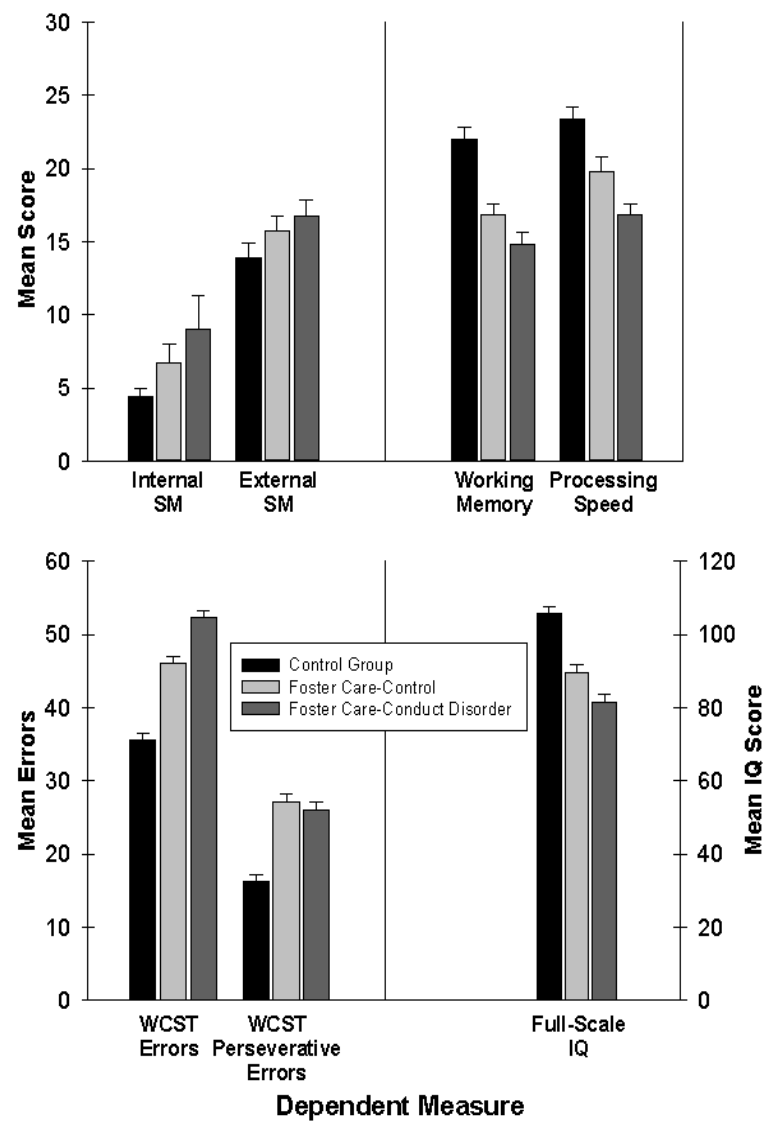

Fig 2. Comparison of Psychiatric Diagnosis / Living Arrangement for Each Dependent Measure

were found, $F(2,82)=9.57, \mathrm{p}<.001, \eta^{2}=.189$. Once again, 6 to 8 -year old participants made significantly more errors than older participants and the two older group performances were similar.

In addition to the age-associated effects in source monitoring performance, WCST performance differed as a function of age on total errors, $F(2,82)=6.97, p<.01, \eta^{2}$ $=.145$, and perseverative errors, $F(2,82)=6.03, p<.01, \eta^{2}$ $=.128$. Multiple comparisons indicated significantly more total errors among 6 to 8 -year olds than 13 to 16 -year olds, with performance of the 9 to 12 -year olds intermediate and not significantly different from either extreme. Thirteen to 16 year old participants made significantly fewer errors than the other two age groups, with the latter two groups not significantly different on this measure. Last, no age associated differences were found on the FS-IQ, WM, and PS measures.

\subsection{Foster-Care Analyses}

As noted above, following verification of an age effect on performance, the data were analyzed using a planned MANCOVA with the two control groups and the conduct-disorder group as the independent variable and age as the covariate. The MANOVA revealed that the psychiatric diagnosis / living arrangement variable was significant, Wilks $\lambda=.454, F(14,150)=5.19, p<.001$. The covariate of age was significant as well, Wilks $\lambda=.556, F(7,75)$ $=8.56, p<.001$. Examination of the univariate analyses showed the following. As was the case for age, group differences were found for ISM measure, $F(2,81)=7.13, p$ $<.01, \eta^{2}=.150$, but not for the ESM measure, $F(2,81)=$ $6.97, p>.10, \eta^{2}=.145$. Post hoc examination of the ISM scores revealed that both the intact family and foster care control groups differed from the foster care / conduct disorder group, with scores in the foster care control group comparable to that of the intact family control group.

Significant differences in FS-IQ were found, $F(2,81)=$ $30.68, p<.001, \eta^{2}=.431$. As can be seen in Fig. 2, children in the intact family control group had significantly higher FS-IQ scores than either foster care group. In addition, FS-IQ scores in the foster care control group were intermediate between that of the intact family control and conduct disorder groups $(p s<.05)$.

On the basis of the preceding results, not surprisingly, group differences were found on the WM, $F(2,81)=21.53$, $p<.001, \eta^{2}=.347$, and PS measures, $F(2,81)=12.28, p$ $<.001, \eta^{2}=.233$, as well. Children in the control group performed better than children in either foster care group with children in the foster care control group performing significantly better than the conduct disordered youth on the PS measure. All three groups differed significantly on the total number of errors, while children in the control group made significantly fewer perseverative errors than that of the foster care groups, with the performance of the latter two comparable.

Last, examination of the WCST measures revealed significant differences among the groups on both total errors, $F(2,81)=8.96, p<.001, \eta^{2}=.181$, and the perseverative errors, $F(2,81)=7.70, \mathrm{p}<.01, \eta^{2}=.160$. Children in the control group made significantly fewer total errors and perseverative errors than either foster care group. However, unlike the total number of errors (see Fig. 2) the number of perseverative errors for the two foster care groups was comparable.

\section{Discussion}

Often children residing in foster-care have siblings. In reviewing a number of studies, Howe and Recchia [57] noted that the shared variance in measured personality is only about $2.25 \%$ [see 56]. Coupled with the finding that the environmental influences on siblings vary considerably [57], even siblings removed from the same home might respond differently engaging in quite different patterns of behavior.

It has been reported that children residing in foster care have significantly higher levels of problems associated with 
their mental well-being [59]. For example, using the Child Behavior Checklist (CBCL)[60], Clausen et al. [59] found that a substantial majority of the children who comprised their sample had clinical mental health issues of clinical significance. Often children residing in foster care appear to suffer from a variety of symptoms associated with neurophysiological dysregulation [61] with much of this phenomenon driven by problems in the hypothalamic pituitary adrenal (HPA) axis [62]. Not surprisingly, such imbalances are linked to negative outcomes [63], with a number of noteworthy deficits in school functioning reported [61, 64-66].

Exacerbating the problem, there may be issues of sibling abuse within the family and/or foster-care unit. For example, Howe and Recchia [57] note that while sibling conflicts are common, violent and abusive inter-sibling conflicts may occur. In many cases, such maladaptive sibling relationships may be seen as typical of childhood sibling rivalries. Unfortunately without intervention abusive sibling relationships appear to be associated a range of aggressive behaviors, the identification of a conduct disorder, and psychopathology [57, 67-70]. Here, boys are disproportionally represented $[67,68]$.

On the other hand, reports from case studies suggest that placing siblings in the same setting is associated with a variety of positive effects including stimulating more supportive inter-sibling roles and closer bonds between siblings [71]. Conversely, when siblings are placed in separate foster homes the effect can be negative leading to behavior problems $[69,72-74]$ and greater foster care placements instability $[69,75]$.

In addition to the influences associated with a variety of environmental factors in the development of conduct disorders, there is evidence of a genetic predisposition as well [76-79]. For example, Deater-Decker and colleagues [76], as part of the Researchers of the Nonshared Environment in Adolescent Development Project, found a heritability coefficient of $70 \%$ for individual differences in externalizing behaviors [see also, 28]. However, findings from the Virginia Twin Study of Adolescent Behavior Development suggested heritability estimates of 24 to $36 \%$ (self-report interviews \& questionnaires) and 27 to $74 \%$ for (parent interviews \& questionnaires)[77]. On the basis of this and other studies, Cappadocia et al. [28] noted that the externalizing behaviors are consistent with aggression commonly seen in these behavioral disorders rather than conduct disorder per se. More recently, evidence has been reported linking a function genetic variant of the promoter section of the gene associated with monoamine oxidase A (MAOA) with the association between childhood maltreatment and the development of a conduct disorder $[79,80]$. MAOA, an enzyme, is involved in the regulation of the catecholamine neurotransmitters dopamine (DA), norepinephrine (NE), and serotonin (5-HT) [81]. Further, variations in the MAOA gene are associated with a number of self-regulatory behavioral problems [79,82], antisocial behaviors, and aggression [79]. Consistent with this, neuroendocrine dysregulation in catecholaminergic systems has been reported in studies of children with histories of exposure to violence $[83,84]$.

With the advances in genetic research, a number of genetic studies have been conducted with the goal of identifying the gene variants associated with a number of behaviors including aggression [85]. The studies have suggested that, at least in males, manifestations of anger are related to gene variants coding for the neurotransmitter serotonin. Often, such variation is associated with different forms of behavior problems [85]. While most studies have examined genetic variation in adult human or animal models [85], a longitudinal study following New Zealand children offers additional insight [80]. Controlling for such factors as childhood abuse, the investigators examined the relationship between the MAOA gene (see above) and aggressive behavior during adolescence and adulthood. Among males who were abused, individuals with the low-activity MAOA variant of the gene were at a significantly higher risk of conviction resulting from violence. Last, in adolescents, an association among those identified with conduct disorder, antisocial personality symptology in adulthood, and a marked predisposition toward violent behavior at the age of 26 was found [80].

Recently, using a mouse model of neuropsychiatric disorders Niwa et al. [86] demonstrated the cumulative effects of stressors on the development of adult-onset psychiatric disorders with a neurological basis [86]. In the study, the authors provided evidence of a glucocorticoid mediated response to stressors that had a direct epigenetic impact on neuronal development and function. Further, the effects of the stressor (isolation) influenced dopaminergic mesocortical neurons but such effects only occurred when the appropriate genetic risk factors were present.

In summary, a large body of evidence exists suggesting that a variety of social factors are associated with the development of conduct disorder, including relevant interpersonal relationships with peers, parents or guardians, and neighbors [28,87-95]. Not surprising but relevant here are the outcomes associated with poor parenting. Inconsistent discipline, laissez-faire supervision of a child, lower involvement, and maladaptive parent-child conflict patterns are associated with the development of a variety of disruptive behaviors including those associated with conduct disorder $[28,89,96]$. In addition, quite often childhood abuse is associated with the development of both conduct disorders and a later diagnosis of antisocial personality disorder [94]. In light of the fact that many studies have demonstrated a link between impoverished neighborhoods and delinquent behavior [see 28,92,93] and relationships with deviant peers is associated with a number of indicators of a conduct disorder including aggression [87,95], a conduct disorder may well be a predicted outcome [28].

The review of the research by Cappadocia et al. [28] is instructive. The authors suggest that the influence of parents begins at birth, with peer influences becoming relevant at the age of five or six $[97,98]$. According to Cappadocia et al. the 
research on parenting indicates that hostile, authoritarian parenting styles with the use of coercion may lead to difficulties in both the processing and expression of emotion [99]. If friendship choices include a number of aggressive peers, then such experiences coupled with the childhood environment (i.e., home and neighborhood) would predispose the child toward engaging in inappropriate aggressive behavior.

In conclusion, the present results add support to a growing body of evidence demonstrating deficits in general cognitive as well as executive functioning among neglected youth. Confusion between the source of information, thought, and behavior could exacerbate the problem. Deficits of this type can impact all facets of life including school performance, behavior in the home and in school settings, as well as in the larger community. Children with greater impairment of the frontal cortices appear to suffer with poor judgment, impulse control, and a tendency toward irritability and aggressive behavior. Thus, it is imperative that relevant social agencies and the educational system intervene as early as possible to ameliorate what could otherwise lead to a destructive path for the youth in question.

\section{Acknowledgments}

A special thank you to K L. S. and B. D for their help with data collection and scoring.

\section{References}

[1] Seguin, J. R., Boulerice, B., Harden, P. W., Tremblay, R. E., \& Pihl, R. O. Executive functions and physical aggression after controlling for attention deficit hyperactivity disorder, general memory and IQ. Journal of Child Psychology and Psychiatry, and Allied Disciplines, 1999;40(8):1197-1208.

[2] Stieben, J., Lewis, M. D., Granic, I., Zelazo, P. D., Segalowitz, S., \& Peplera, D. Neurophysiological mechanisms of emotion regulation for subtypes of externalizing children. Development and Psychopathology, 2007; 19:455-80.

[3] Caramaschi, D., de Boer, S. F., de Vries, H., \& Koolhaas, J. M. Development of violence in mice through repeated victory along with changes in prefrontal cortex neurochemistry. Behavioural Brain Research, 2008;189:263-72.

[4] Hawkins, K. A., \& Trobst, K. K. Frontal lobe dysfunction and aggression: Conceptual issues and research findings. Aggression and Violent Behavior, 2000;5: 147-57.

[5] Dahl, R. E. Affect regulation, brain development, and behavioral0emotional health in adolescence. CNS Spectrums, 2001;6: 60-72.

[6] Grafman, J., Schwab, K.,Warden, D.,\& Pridgen, A. Frontal lobe injuries, violence, and aggression: A report of the Vietnam head injury study. Neurology, 1996;46:1231-38.

[7] Volkow, N. D., \& Tancredi, L. Neural substrates of violent behaviour: A preliminary study with positron emission tomography. British Journal of Psychiatry, 1987;151:668-73.
[8] Damasio, A. R., Grabowski, T. J., Bechara, A., Damasio, H., Ponto, L. L. B., Parvizi, J., et al. Subcortical and cortical brain activity during the feeling of self-generated emotions. Nature Neuroscience, 2000; 3:1049-56.

[9] Blair, R. J. R. Neurocognitive models of aggression, the antisocial personality disorders, and psychopathy. Journal of Neurology, Neurosurgery and Psychiatry, 2001;71:727-31.

[10] Rolls, E. T. The Brain and emotion. New York: Oxford University Press; 1999.

[11] Rolls, E. T. Emotion explained. Oxford, UK: Oxford University Press; 2005.

[12] Shamay-Tsoory, S. G., Harari, H., Aharon-Peretz, J., \& Levkovitz, Y. The role of the orbitofrontal cortex in affective theory of mind deficits in criminal offenders with psychopathic tendencies. Cortex, 2010;46:668-77.

[13] Botvinick, M. M., Cohen, J. D., \& Carter, C. S. Conflict monitoring and anterior cingulate cortex: An update. Trends in Cognitive Sciences, 2004; 8:539-46.

[14] Posner, M. I., \& Rothbart, M. K. Developing mechanisms of self-regulation. Development and Psychopathology, 2000;12:427-41.

[15] Finkelhor, D., Ormrod, R., Turner, H., \& Hamby, S. L. The victimization of children and youth: A comprehensive, national survey. Child Maltreatment, 2005;10:5-25.

[16] Perkins, S., \& Graham-Bermann, S. Violence exposure and the development of school-related functioning: Mental health, neurocognition, and learning. Aggression and Violent Behavior,2012;17:89-98.

[17] Andersen, S., Tomada, A., Vincow, E., Valente, E., Polcari, A., \& Teicher, M. Preliminary evidence for sensitive periods in the effect of childhood sexual abuse on regional brain development. The Journal of Neuropsychiatry and Clinical Neurosciences, 2008;20:292-301.

[18] Choi, J., Jeong, B., Rohan, M., Polcari, A., \& Teicher, M. Preliminary evidence for white matter tract abnormalities in young adults exposed to parental verbal abuse. Biological Psychiatry,2009;65:227-34.

[19] Miskovic, V., Schmidt, L., Georgiades, K., Boyle, M., \& Macmillan, H. Adolescent females exposed to child maltreatment exhibit atypical EEG coherence and psychiatric impairment: Linking early adversity, the brain, and psychopathology. Development and Psychopathology, 2010;22:419-32.

[20] Seckfort, D. Paul, R., Grieve, S.M., Vandenberg, B, Byrant, R., Williams, L.M., Clark, C.R., Cohen, R.A., Bruce, S. E., \& Gordon, E. The impact of early life stress on brain structure and function across the lifespan. Brain Imaging and Behavior,2008;2:49-58.

[21] deBellis, M. D., Hooper, S. R., Spratt, E. G., \& Woolley, D. P. Neuropsychological findings in childhood neglect and their relationships to pediatric PTSD. Journal of the International Neuropsychological Society, 2009;15:868.

[22] DePrince, A., Weinzierl, K., \& Combs, M. Executive function performance and trauma exposure in a community sample of children. Child Abuse \& Neglect, 2009;33:353-61. 
[23] El-Hage, W., Gaillard, P., Isingrini, M., \& Belzung, C. (2006). Trauma-related deficits in working memory. Cognitive Neuropsychiatry,2006;11:33-46.

[24] Watts-English, T., Fortson, B. L., Gibler, N., Hooper, S. R., \& DeBellis, M. D. The psychobiology of maltreatment in childhood. Journal of Social Issues, 2006;62: 717-36.

[25] American Psychiatric Association. Diagnostic and statistical manual of mental disorders IV-R. American Psychiatric Press; 2000 .

[26] Flor-Henry, P. Psychosis, neurosis, and epilepsy: Developmental and gender-related effects and their aetiological contribution. British Journal of Psychiatry,1974;124:144-50.

[27] Pontius, A. A., \& Ruttiger, K. F. Frontal lobe system maturational lag in juvenile delinquents shown in narratives test. Adolescence, 1976;11:509-18.

[28] Cappadocia, M. C., Desrocher, M., Pepler, D., \& Schroeder, J. $\mathrm{H}$. Contextualizing the neurobiology of conduct disorder in an emotion dysregulation framework. Clinical Psychology Review, 2009;29:506-18.

[29] Frick, P. J. Conduct disorders and severe antisocial behaviour. New York: Plenum; 1998.

[30] Frick, P. J., \& Dickens, C. Current perspectives on conduct disorder. Current Psychiatry Reports, 2006; 8:59-72.

[31] Christian, R. E., Frick, P. J., Hill, N. L., Tyler, L. \& Frazer, D. R. Psychopathy and conduct problems in children: II. Implications for subtyping children with conduct problems. Journal of the American Academy of Child \& Adolescent Psychiatry, 1997; 36:233-41.

[32] Frick, P. J., \& Hare, R. The Antisocial Process Screening Device. Toronto: Multi-Health Systems; 2001.

[33] Dadds, M. R., Fraser, J., Frost, A., \& Hawes, D. J. Disentangling the underlying dimensions of psychopathy and conduct problems in childhood: A community study. Journal of Consulting and Clinical Psychology, 2005; 73:400-10.

[34] Nadel, L. Multiple memory systems: A new view. In: R. Menzel \& J. H. Byrne, editors, Learning and memory: A comprehensive reference (Vol. 1) (pp. 41-52). New York: Academic Press; 2008.

[35] Eichenbaum, H. Introduction and Overview. In $H$. Eichenbaum \& J. H. Byrne, editors, learning and memory: A comprehensive reference (Vol. 3) (pp. 1-8). New York: Academic Press; 2008.

[36] Squire, L. R. Declarative and nondeclarative memory: Multiple brain systems supporting learning and memory. In D. L. Schacter \& E. Tulving, editors, Memory Systems 1994 (pp. 203-231). Cambridge, MA: MIT Press; 1994.

[37] Squire, L. R., \& Shrager, Y. Declarative memory system: Amnesia. In H. Eichenbaum \& J. H. Byrne, editors, Learning and memory: A comprehensive reference (Vol. 3) (pp. 67-78). New York: Academic Press; 2008.

[38] Eichenbaum, H., \& Cohen, N. J. From Conditioning to Conscious Recollection: Memory Systems of the Brain. Oxford Psychology Series, no. 35. New York: Oxford University Press; 2001.

[39] Drummey, A. B., \& Newcombe, N. S. Developmental changes in source memory. Developmental Science, 2002; 5:502-13.

[40] Johnson, M. K., Hashtroudi, S., \& Lindsay, D. S. Source monitoring. Psychological Bulletin, 1993;114: 3-28.

[41] Smeets, T., Jelicic, M., Merckelbach, H., Peters, M., Fett, A., Taverniers, J., Henquet, C. \&, Dautzenberg, J. (2006). Enhanced memory performance on an internal-internal source monitoring test following acute psychosocial stress. Behavioral Neuroscience,2006;120:1204-10.

[42] Johnson, M. K. Discriminating the origin of information. InT. F. Oltmanns \& B. A. Maher, editors, Delusional beliefs (pp. 34-65). New York: Wiley; 1988.

[43] Johnson, M. K. Reality monitoring: An experimental phenomenological approach. Journal of Experimental Psychology: General, 1988; 117:390-94.

[44] Lindsay, D. S., \& Johnson, M. K. Reality monitoring and suggestibility: Children's ability to discriminate among memories from different sources. In S. J. Ceci, M. P. Toglia, \& D. F. Ross, editors, and Children's eyewitness memory (pp. 92-121). New York: Springer-Verlag; 1987.

[45] Lindsay, D. S., Johnson, M. K., \& Kwon, P. Developmental changes in memory source monitoring. Journal of Experimental Child Psychology, 1991; 52:297-318.

[46] Ross, D. F., Ceci, S. J., Dunning, D., \& Toglia, M. P. Unconscious transference and mistaken identity: When a witness misidentifies a familiar but innocent person. Journal of Applied Psychology, 1994; 79:918-30.

[47] Gopnik, A., \& Graf, P. (1988). Knowing how you know: Young children's ability to identify and remember the source of their beliefs. Child Development, 1988; 59:1366-71.

[48] Taylor, M., Esbensen, B.M., \& Bennett, R.T. Children's understanding of knowledge acquisition: the tendency for children to report that they have always known what they have just learned. Child Development, 1994; 65:1581-1604.

[49] Wimmer, H., Hogrefe, G. J., \& Perner, J. (1988). Children understand of informational access as a source of knowledge. Child Development, 1988; 59:386-96.

[50] Foley, M. A., \& Johnson, M. K. Confusions between memories for performed and imagined actions: A developmental comparison. Child Development, 1985; 56:1145-55.

[51] Foley, M. A., Johnson, M. K., \& Raye, C. L. (1983). Age-related changes in confusion between memories for thoughts and memories for speech. Child Development, 1983; 54:51-60.

[52] Heaton, R. K., Chelune, G. J., Talley, J. L., Kay, G. G., \& Curtiss, G. Wisconsin Card Sort Test, Manual. Odessa, FL: Psychological Assessment Resources; 1993.

[53] Wechsler, D. Wechsler Intelligence Scale for Children (3rd Ed.). San Antonio, TX: The Psychological Corporation; 1991.

[54] Boll, T. Children's category test. San Antonio, TX: Psychological Corporation; 1993.

[55] Sattler, J. M. Assessment of children ( $3^{\text {rd }}$ ed.). San Diego: Author; 1992.

[56] Williams, P. E., Weiss, L. G., \& Rolfus, E. WISC-IV Tech- 
nical report \#1: Theoretical model and blueprint. Accessed June 5, 2004 from http://www.pearsonassessments.com/hai/Images/pdf/wisciv/ WISCIVTechReport1.pdf

[57] Howe, N., \& Recchia, H. E. Siblings and sibling rivalry. In M. M. Haith \& J. B. Benson, editors, Encyclopedia of infant and early childhood development vol. 3 (pp. 154-164). San Diego, CA: Academic; 2008.

[58] Dunn, J., \& Plomin, R. Separate Lives: Why Siblings are so different. New York, NY: Basic; 1990.

[59] Clausen, J. M., Landsverk, J., Ganger, W., Chadwick, D., \& Litrownik, A. Mental health problems of children in foster care. Journal of Child and Family Studies, 1998;7:283-96.

[60] Achenbach, T. M. Manual for the child behavior checklist/4-18 and 1991 profile. Burlington, VT: University of Vermont; 1991

[61] Healey, C. V., \& Fisher, P. A. Young children in foster care and the development of favorable outcomes. Children and Youth Services Review, 2011; 33:1822-30.

[62] Bruce, J., Fisher, P. A., Pears, K. C., \& Levine, S. Morning cortisol levels in preschool-aged foster children: Differential effects of maltreatment type. Developmental Psychobiology, 2009 ; 51:14-23.

[63] Fisher, P. A., Stoolmiller, M., Gunnar, M. R., \& Burraston, B. O. Effects of a therapeutic intervention for foster preschoolers on diurnal cortisol activity. Psychoneuroendocrinology, 2007; 32:892-905.

[64] Brooks, D., \& Barth, R. P. Characteristics and outcomes of drug-exposed and nondrug-exposed children in kinship care and non-relative foster care. Children and Youth Services Review, 1998; 20:475-501.

[65] Fantuzzo, J., \& Perlman, S. The unique impact of out-of-home placement and the mediating effects of child maltreatment and homelessness on early school success. Children and Youth Services Review, 2007; 29:941-60.

[66] Zima, B. T., Bussing, R., Freeman, S., Yang, X., Belin, T. R., \& Forness, S. R. Behavior problems, academic skill delays and school failure among school-aged children in foster care: Their relationship to placement characteristics. Journal of Child and Family Studies, 2000; 9:87-103.

[67] Duncan, R. D. Peer and sibling aggression: An investigation of intra- and extra-familial bullying. Journal of Interpersonal Violence, 1999; 14:871-86.

[68] Dunn, J. Brothers and sisters in middle childhood and early adolescence: Continuity and change in individual differences In G. H. Brody, editor,, Sibling relationships: Their causes and consequences (pp. 31-46). Norwood, NJ 7 Ablex; 1996.

[69] Linares, L. O. An understudied form of intra-family violence: Sibling-to-sibling aggression among foster children. Aggression and Violent Behavior, 2006;11:95-109.

[70] Stocker, C. M., Burwell, R. A., \& Briggs, M. L. Sibling conflict in middle childhood predicts children's adjustment in early adolescence. Journal of Family Psychology, 2002; 16:50-7.

[71] Bellwood, P. Assessing siblings for family placement.
Adoption and Fostering, 1985; 9:33-4.

[72] Aldridge, M. J., \& Cautley, P. W. Placing siblings in same foster home. Child Welfare, 1976; 55:85- 93.

[73] Hegar, R. L. Sibling relationships and separations: Implications for child placement. Social Service Review, 1988; 62:446-67.

[74] Thorpe, M. B., \& Swart, G. T. Risk and protective factors affecting children in foster care: A pilot study of the role of siblings. Canadian Journal of Psychiatry, 1992; 37:616- 22.

[75] Boer, F., \& Spiering, S. M. Siblings in foster care: Success and failure. Child Psychiatry and Human Development, 1991; 21:291-300.

[76] Deater-Deckard, K., Reiss, D., Hetherington, E. M., \& Plomin, R. Dimensions and disorders of adolescent adjustment: A quantitative genetic analysis of unselected samples and selected extremes. Journal of Child Psychology and Psychiatry, 1997; 38:515-25.

[77] Eaves, L. J., Silberg, J. L., Meyer, J. M., Maes, H. H., Simonoff, E., Pickles, A., et al. Genetics and developmental psychopathology: 2. The main effects of genes and environment on behavioral problems in the Virginia twin study of adolescent behavioral development. Journal of Child Psychology and Psychiatry, 1997; 38:965-80.

[78] Edelbrock, C., Rende, R., Plomin, R., \& Thompson, L. A. A twin study of competence and problem behavior in childhood and early adolescence. Journal of Child Psychology and Psychiatry, 1995; 36:775-85.

[79] Kim-Cohen, J., Caspi, A., Taylor, A., Williams, B., Newcombe, R., Craig, I. W., et al. MAOA, maltreatment, and gene-environment interaction predicting children's mental health: New evidence and a meta-analysis. Molecular Psychiatry, 2006; 11:903-13.

[80] Fergusson, D. M., Boden, J. M., Horwood, L. J., Miller, A. L., \& Kennedy, M. A. MAOA, abuse exposure and antisocial behaviour: 30-year longitudinal study. British Journal of Psychiatry, 2011; 198:457-63.

[81] Mead, H. K., Beauchaine, T. P., \& Shannon, K. E. Neurobiological adaptations to violence across development. Development and Psychopathology, 2010; 22:1-22.

[82] Oades, R., Lasky-Su, J., Christiansen, H., Faraone, S., Sonuga-Barke, E., Banaschewski, T., et al. The influence of serotonin- and other genes on impulsive behavioral aggression and cognitive impulsivity in children with attention-deficit/hyperactivity disorder (ADHD): Findings from a family-based association test (FBAT) analysis. Behavioral and Brain Functions, 2008;4(48): 48.

[83] DeBellis, M. D. Developmental traumatology: The psychobiological development of maltreated children and its implications for research, treatment, and policy. Development and Psychopathology, 2001;13:539-64.

[84] DeBellis, M. D., Baum, A. S., Birmaher, B., Keshavan, M. S., Eccard, C. H., Boring, A. M., Jenkins, F. J., et al. (1999). A.E. Bennett Research Award. Developmental traumatology Part I: Biological stress systems. Biological Psychiatry, 1999; 45:1259-70.

[85] Tremblay, R. E. Anger and aggression. In M. M. Haith \& J. B. 
Benson, editors, Encyclopedia of infant and early childhood development vol. 1 (pp. 62-74). San Diego, CA: Academic; 2008.

[86] Niwa, M., Jaaro-Peled, H., Tankou, S., Seshadri, S., Hikida, T., Matsumoto, Y., Cascella, N. G., Frick, P. J., Lahey, B. B., Loeber, R., Stouthamer-Loeber, M., Christ, M. A. G., \& Hanson, K. Familial risk factors to oppositional defiant disorder and conduct disorder: Parental psychopathology and maternal parenting. Journal of Consulting and Clinical Psychology, 1992; 60:49-55.

[87] Barnow, S., Lucht, M., \& Freyberger, H. Correlates of aggressive and delinquent conduct problems in adolescence. Aggressive Behavior, 2005; 31:24-39.

[88] Fergusson, D. M., Horwood, J., \& Lynskey, M. T. Childhood sexual abuse and psychiatric disorder in young adulthood: II. Psychiatric outcomes of childhood sexual abuse. Journal of the American Academy of Child and Adolescent Psychiatry, 1996; 34:1365-74

[89] Frick, P. J., Lahey, B. B., Loeber, R., Stouthamer-Loeber, M., Christ, M. A. G., \& Hanson, K. Familial risk factors to oppositional defiant disorder and conduct disorder: Parental psychopathology and maternal parenting. Journal of Consulting and Clinical Psychology, 1992; 60:49-55.

[90] Haapasalo, J., \& Tremblay, R. E. Physically aggressive boys from ages 6 to 12: Family background, parenting behavior, and prediction of delinquency. Journal of Consulting and Clinical Psychology, 1994; 62:1044-52.

[91] Herrenkohl, T. I., Maguin, E., Hill, K. G., Hawkins, J. D., Abbott, R. D., \& Catalano, R. F. Developmental risk factors for youth violence. Journal of Adolescent Health, 2000; 26:176-86.

[92] Kroneman, L., Loeber, R., \& Hipwell, A. E. Is neighborhood context differently related to externalizing problems and delinquency for girls compared with boys? Clinical Child and Family Psychology Review, 2004; 7:109-122.
[93] Loeber, R., Green, S. M., Keenan, K., \& Lahey, B. B. Which boys will fare worse? Early predictors of the onset of conduct disorder in a six-year longitudinal study. Journal of the American Academy of Child and Adolescent Psychiatry, 1995;34:499-509.

[94] Luntz, B. K., \& Widom, C. S. Antisocial personality disorder in abused and neglected children grown up. The American Journal of Psychiatry, 1994; 151:670-74.

[95] Snyder, J., Schrepferman, L., Oeser, J., Patterson, G., Stoolmiller, M., Johnson, K., et al. Deviancy training and association with deviant peers in young children: Occurrence and contribution to early-onset conduct problems. Development and Psychopathology, 2005; 17:397-413.

[96] Wasserman, G. A., Miller, L. S., Pinner, E., \& Jaramillo, B. Parenting predictors of early conduct problems in urban, high-risk boys. Journal of the American Academy of Child and Adolescent Psychiatry, 1996; 35:1227-36.

[97] Miller-Johnson, S., Coie, J. D., Maumary-Gremaud, A., \& Bierman, K. The Conduct Problems Prevention Research Group. Peer rejection and aggression and early starter models of conduct disorder. Journal of Abnormal Child Psychology, $2002 ; 30: 217-30$.

[98] Morrell, J., \& Murray, L. Parenting and the development of conduct disorder and hyperactive symptoms in childhood: A prospective longitudinal study from 2 months to 8 years. Journal of Child Psychology and Psychiatry, 2003; 44: 489-508.

[99] Farrington, D. P. Childhood aggression and adult violence: Early precursors and later-life outcomes. In D.J. Pepler, K.H. Rubin, \& Earlscourt Child and Family Centre, editors, The development and treatment of childhood aggression (pp. 5-30). Hillsdale, NJ: Lawrence Erlbaum; 1991. 